\title{
A myricaceous male inflorescence with pollen in situ from the middle Eocene of Europe
}

\author{
Volker Wilde $^{1} \cdot$ Herbert Frankenhäuser ${ }^{2}$ - Olaf Klaus Lenz ${ }^{3,4}$
}

Received: 17 April 2020 / Revised: 23 July 2020 / Accepted: 17 December 2020 / Published online: 28 April 2021

(C) The Author(s) 2021

\begin{abstract}
The late middle Eocene lacustrine filling of a maar lake at Eckfeld (Eifel Hills, Rhineland-Palatinate, western Germany) has provided four specimens of male inflorescences (catkins) in different stages of anthesis, each with pollen preserved in situ. The appearance of the successive stages together with triporate pollen showing an irregular surface and a myricoid microornamentation clearly suggests an assignment of the fossil catkins to the Myricaceae. The material is described as a new genus and new species and represents the oldest record of male catkins for the family. The in situ preserved pollen grains are comparable to dispersed grains of Triatriopollenites excelsus.
\end{abstract}

Keywords Paleogene $\cdot$ Fagales $\cdot$ Myricaceae $\cdot$ Palynology $\cdot$ Pollen morphology $\cdot$ Triatriopollenites $\cdot$ Catkin

\section{Introduction}

Several middle Eocene plant taphocoenoses are known from Germany, especially from the lignite mining districts of the Geiseltal and Helmstedt and the lacustrine fillings ("oilshales") of the maar structures at Messel and Eckfeld. The Geiseltal is well known for leaves, fruits/seeds (compilation in Wilde 1995), and pollen/spores (compilation in Krutzsch 1976). Helmstedt has provided some leaves (Wilde 1989a) and a rich association of pollen and spores (e.g. Lenz 2005). The early middle Eocene bituminous clays of the famous UNESCO World Nature Heritage Site at Messel have been studied

Volker Wilde

Volker.Wilde@senckenberg.de

1 Senckenberg Forschungsinstitut und Naturmuseum, Sektion Paläobotanik, Senckenberganlage 25, 60325 Frankfurt am Main, Germany

2 Johannes Gutenberg-Universität Mainz, Institut für Organismische und Molekulare Evolutionsbiologie, AG Diversität der Blütenpflanzen, Anselm-Franz-von-Bentzel-Weg 9 a, 55128 Mainz, Germany

3 Senckenberg Gesellschaft für Naturforschung, General Directorate, Senckenberganlage 25, 60325 Frankfurt am Main, Germany

4 Technische Universität Darmstadt, Institute of Applied Geosciences, Applied Sedimentology, Schnittspahnstrasse 9, 64287 Darmstadt, Germany intensely for plant macrofossils (for compilations see Wilde 2004; Collinson et al. 2012) and microfossils (Thiele-Pfeiffer 1988).

The organic-rich sediments from the Eckfeld-Maar (Eifel Hills, Rhineland-Palatinate, western Germany) represent another lagerstätte (e.g. Neuffer et al. 1996) which is late middle Eocene in age (Franzen 1993) and provides not only exceptionally preserved vertebrates and insects but also a wealth of plant fossils including leaves, fruits/seeds and pollen (compilation in Wilde and Frankenhäuser 1998). Similar to Messel, a considerable number of flowers has been recovered from the site, frequently with pollen preserved in situ (Frankenhäuser and Wilde 1993). For the present study, we introduce a distinct type of catkin-like male inflorescences of putative myricaceous affinity with pollen in situ.

The Myricaceae comprise four extant genera: Myrica, Morella, Comptonia, and Canacomyrica (e.g. Sundberg 1985; Wilbur 1994; Herbert 2005a). Today, they are found on all continents except Australia, preferentially in subtropical to temperate climates (e.g. Mai 1995; Heywood 1993; Herbert 2005a). The closely related genera Myrica and Morella for a long time have frequently been treated as infrageneric taxa (e.g. Engler 1894; Abbe 1974; Macdonald 1989); however, their distinction has eventually been accepted in more recent papers (e.g. Wilbur 1994; Herbert 2005b). Comptonia is a monospecific genus today restricted to eastern and central North America. Canacomyrica is also monospecific and today endemic to New Caledonia (e.g. Herbert 2005a). 
Leaves of Myricaceae have frequently been described back into the Cretaceous, but many of these and other records of the family should be treated with caution (Chourey 1974). However, in any case, according to leaves, fruits/seeds, and pollen, the family most probably dates back into the Late Cretaceous (e.g. Muller 1981; Mai 1995; Ferguson 1998). To our knowledge, only a single record of a myricaceous inflorescence has hitherto been described from the fossil record (Kohlman-Adamska et al. 2004).

Among the leaves from Eckfeld, Myricaceae have already been recognised in a preliminary overview of the flora by Wilde (1989b). Later, those which could clearly be assigned to Comptonia were described in detail by Wilde and Frankenhäuser (1999). Other middle Eocene plant taphocoenoses in Germany, such as the Geiseltal (Rüffle 1976) and Messel (Wilde 1989a), have also provided some leaves which were determined as belonging to Myrica and Comptonia. Dispersed myricaceous pollen is well known from the Paleogene of Germany (Thomson and Pflug 1953), including Messel (Thiele-Pfeiffer 1988) and Eckfeld (Nickel 1996).

\section{Material and methods}

The material for the present study has been recovered from the late middle Eocene lacustrine oilshale of the Eckfeld Maar (Eifel Hills, Rhineland-Palatinate, western Germany) by scientific excavations. There are four individual specimens (MNHM PB 2000/2 LS, MNHM PB 2000/7 LS, MNHM PB 2000/9 LS, MNHM PB 2020/577 LS) representing a distinct type of catkin-like male inflorescences with characteristic triporate pollen in situ. They are preserved as compressions, two of them with part and counterpart; the second had been broken longitudinally, and both parts have later been glued together. The material is stored in the Naturhistorisches Museum Mainz/ Landessammlung für Naturkunde Rheinland-Pfalz.

The individual specimens were prepared under water by thoroughly removing obscuring sediment from the surface by scratching with fine steel needles (insect minuteneedles) which were modified into a hook at the tip. The individual fossils were digitally documented by a LEICA MZ 16 FA stereomicroscope which was coupled to a LEICA DFC490 camera. The material is now permanently stored in glycerol to prevent from drying and cracking. An epi-macrofluorescence setup combined to the abovementioned stereomicroscope and camera was applied for studying and documenting the distribution of pollen, trichomes, and cuticle on the fossils.

Pollen has been removed from the fossils with the help of a WILD MZ 8 microscope under microfluorescence control, again by applying fine steel needles. The extract has been washed in distilled water and split for light microscopy (LM) and scanning electron microscopy (SEM). LM preparations were imbedded in glycerine jelly and studied by a LEICA Metallux 3 microscope. The material for SEM was mounted on pieces of photographic film, sputtered with gold, and observed in a JEOL FM6490 LV.

Extant pollen for comparison was derived from different sources. Sheets of flowering Rhoiptelea chiliantha Diels and Hand.-Mazz. were provided by the Herbier Muséum National d'Histoire Naturelle Paris (sheets MNHN-P-P06811850 and P06811852 from Kwangsi Province, China). Platycarya strobilacea Siebold and Zucc. was collected in the Botanical Garden of the University of Zurich, Switzerland, and Casuarina equsetifolia $\mathrm{L}$. was taken from cultivated plants near Faro, Potugal. Carya cordiformis (Wangenh.) K. Koch, Comptonia peregrina (L.) J.M. Coult., Corylus colurna L., Betula papyrifera Marshall, and Myrica gale L. were obtained from cultivated plants in the Botanical Garden of the Johannes Gutenberg University, Mainz.

Extant pollen was acetolyzed following standard methods and split for LM and SEM.

\section{Systematic description}

Genus Myricamentum gen. nov.

Myricamentum eckfeldensis sp. nov.

Holotype: MNHM PB 2000/7 LS (Figs. 1c, c1, 2d-f, 3c)

Paratypes: MNHM PB 2020/577 LS, MNHM PB 2000/2 LS and MNHM PB 2000/9 LS

Derivatio nominis: Catkins of myricaceous affinity (for genus) and locality (for species)

Diagnosis: Elongate male inflorescence (catkin), cylindrical, unbranched, obtuse at the tip, length without peduncle 1-1,5 $\mathrm{cm}$, width 3-5 $\mathrm{mm}$, length of peduncle $4-7 \mathrm{~mm}$, width of peduncle ca. $1 \mathrm{~mm}$. Inflorescence consisting of individual "units" (=male flowers) which are arranged in a gentle spiral. Individual "units" consisting of small concave deltoid scales (bracts) with a small upward pointing tip. Several anthers at the base of each bract (number unclear), individual anthers with short filament and four pollen sacs. Surface of inflorescence covered by peltate scales. Pollen rounded triangular, triporate with prominent pores at the edges and a myricaceous surface of the exine.

Material: Holotype and paratypes are stored in the Naturhistorisches Museum Mainz/Landessammlung für Naturkunde Rheinland-Pfalz under the accession numbers MNHM PB 2000/7 LS (Holotype), MNHM PB 2020/577 LS, MNHM PB 2000/2 LS and MNHM PB 2000/9 LS (Paratypes)

Locality, age and strata: Late middle Eocene lacustrine filling of the Eckfeld Maar (Eckfeld, Eifel Hills, RhinelandPalatinate, western Germany; 50.114593 N, 6.818830 E) 

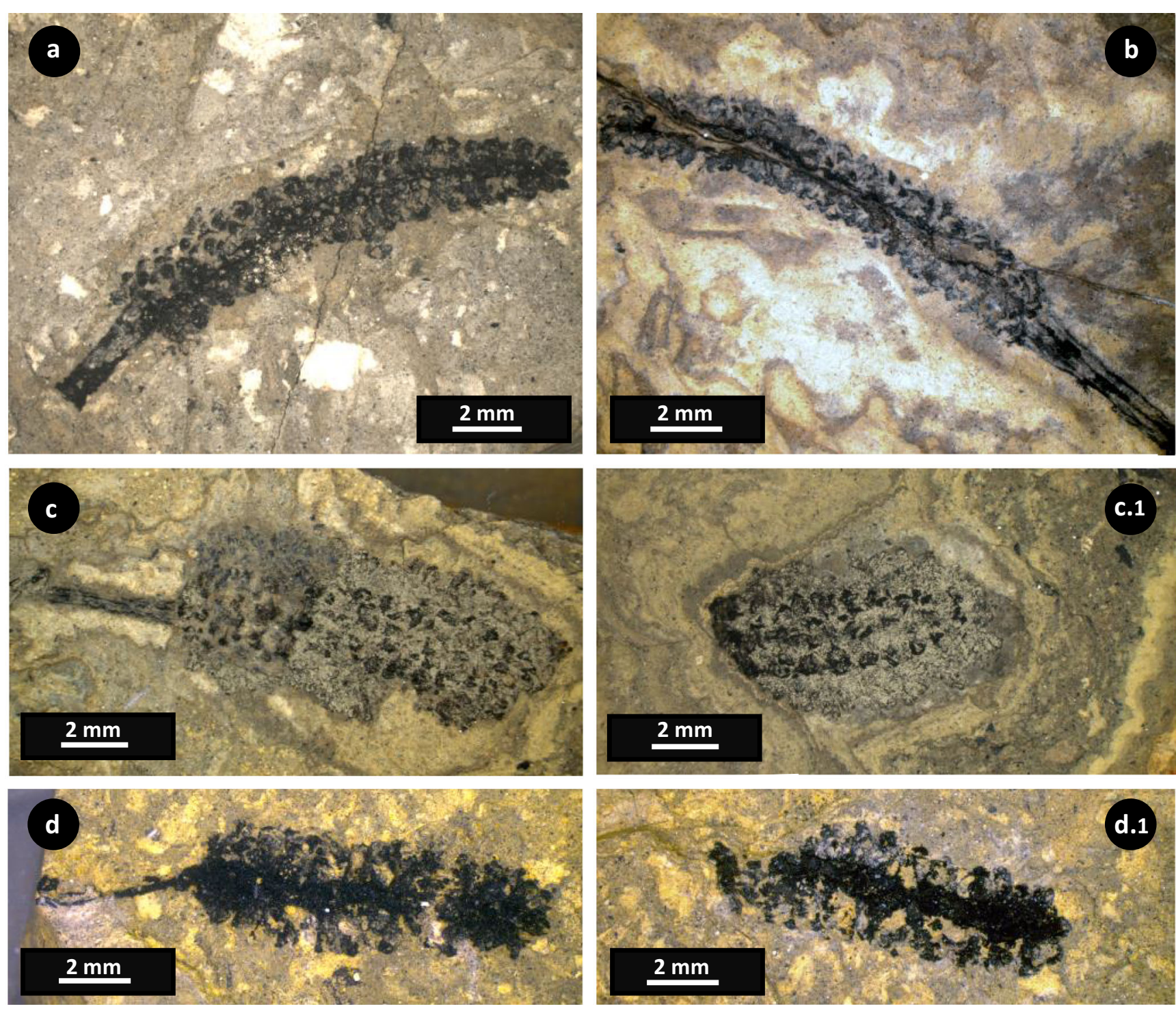

Fig. 1 Catkins of Myricamentum eckfeldensis n. gen. et sp. from the middle Eocene of Eckfeld (Eifel Hills, Rhineland-Palatinate, western Germany). a Specimen MNHM PB 2020/577 LS, complete male inflorescence in preanthesis. b Specimen MNHM PB 2000/2 LS, male inflorescence in preanthesis (glued together from two fragments). c, c.1 Part

\section{Description of specimens}

The material consists only of male inflorescences which are not branched and appear as catkins. The four specimens represent different stages in the development of the inflorescence. Two of them show compact inflorescences in preanthesis (MNHM PB 2020/577 LS and MNHM PB 2000/2 LS, Fig. 1a, b), one is in anthesis with spreading anthers (Holotype MNHM PB 2000/7 LS, Fig. 1c, c1) and another, which shows only the empty framework of axes and scales, is probably preserved in postanthesis (MNHM PB 2000/9 LS, Fig. 1d, d1).

The two complete inflorescences in preanthesis are elongate-cylindrical and obtuse at the apex (Fig. 1a, b). There is a comparatively strong peduncle at the base (Fig.

and counterpart of holotype MNHM PB 2000/7 LS, male inflorescence in full anthesis with spreading anthers. d, d.1 Part and counterpart of specimen MNHM PB 2007/9 LS, postfloral stage of male inflorescence with most of anthers and pollen having been shed

1a, b). The individual catkins are $15 \mathrm{~mm}$ (MNHM PB 2020/ 577 LS, Fig. 1a) and 19 mm (MNHM PB 2000/2 LS, Fig.1b) long and $3 \mathrm{~mm}$ wide; the peduncle in the latter is about $6 \mathrm{~mm}$ long and about $1 \mathrm{~mm}$ wide. The rhachis of each of the two inflorescences gives rise to a great number of small, spirally arranged and imbricate bracts (Figs. 1a, b, 2a-c). Each bract is ovoid acuminate (Fig. 2a, b, c). The adaxial side of the bract is concave Fig. 1c). There is a single male flower in the axil of each bract. The flowers consist of individual anthers, the number of which remains unclear (Fig. 2b, d-f). A perianth is obviously missing. The anthers have a short filament and consist of four pollen sacs (Fig. 2g, h). The surface of the male inflorescence is covered by peltate trichomes which are only locally exposed due to preparation (Fig. 3a). 

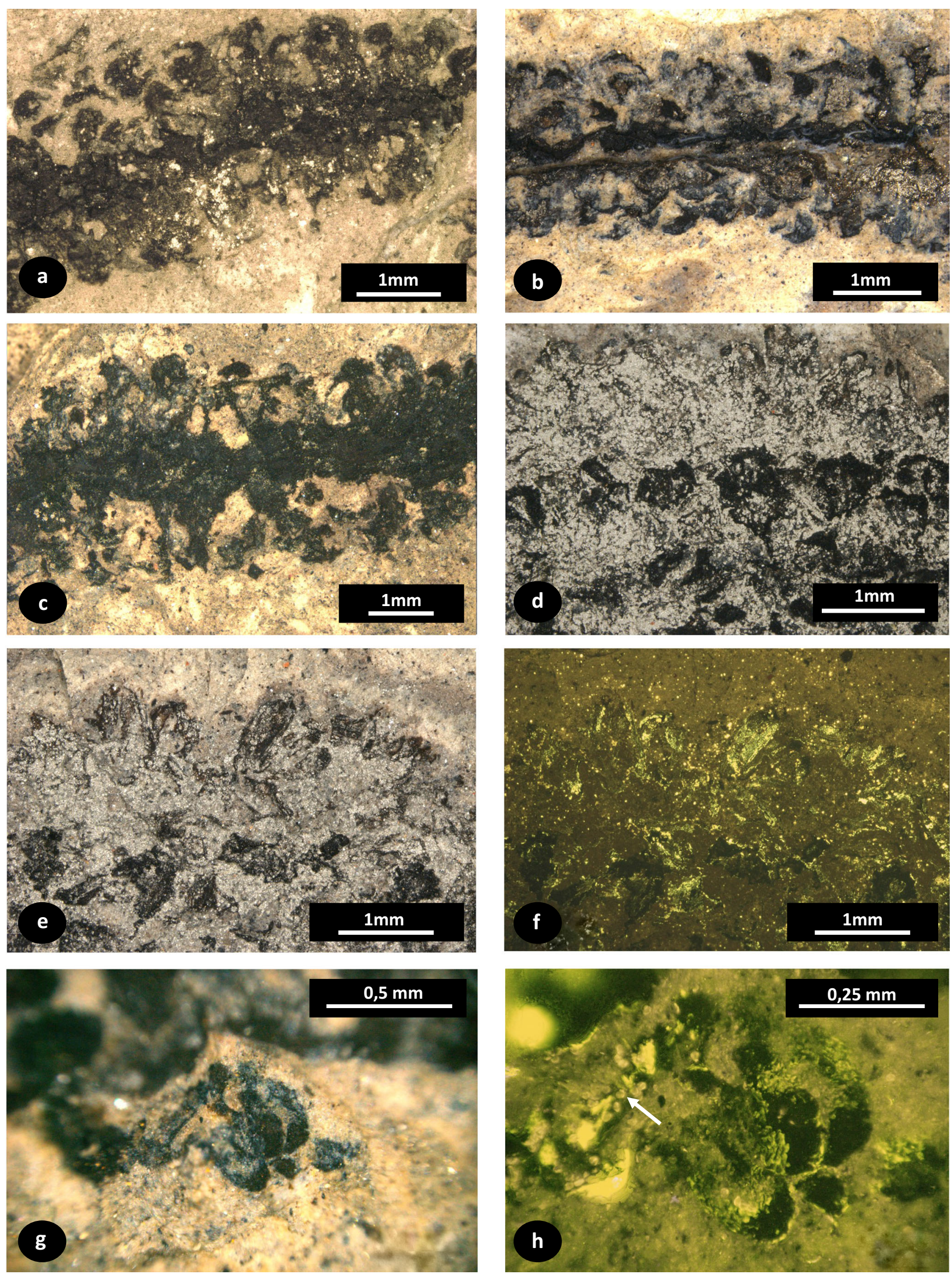
4 Fig. 2 Details from catkins of of Myricamentum eckfeldensis n. gen. et sp. from the middle Eocene of Eckfeld (Eifel Hills, Rhineland Palatinate, western Germany). a Detail from specimen in preanthesis with tightly adpressed bracts, MNHM PB 2020/577 LS b Detail from the second specimen in preanthesis also showing tightly adpressed bracts, MNHM PB 2000/2 LS c Detail from specimen in postfloral stage showing empty space between remaining bracts, MNHM PB 2000/9 LS d Detail from holotype MNHM PB 2000/7 LS, bracts isolated by spreading of the catkin. e Detail from holotype MNHM PB 2007/7 LS with individual anthers and bracts separated and exposed by spreading of the catkin. $\mathbf{f}$ Epifluorescence of the same area than in e showing brightly shining pollen in situ. g Detail from MNHM PB 2020/577 LS, anther with four pollen sacs. $\mathbf{h}$ Epifluorescence of detail from $\mathbf{g}$ showing associated pollen grains (arrow)

The holotype (MNHM PB 2000/7 LS, Fig. 1c with counterpart c1) shows a staminate inflorescence in anthesis (=with spreading anthers). The inflorescence itself is $16 \mathrm{~mm}$ long and $3 \mathrm{~mm}$ wide (including the anthers $17 \mathrm{~mm}$, respectively $4 \mathrm{~mm}$ ). The peduncle is $5 \mathrm{~mm}$ long and $1 \mathrm{~mm}$ wide. The bracts are more loosely arranged in a flat spiral (Figs. 1c, c1), about $0.7 \mathrm{~mm}$ long (Fig. 2d) and show numerous anthers and pollen in between (Figs. 1c, c1, 2d-f). Therefore, the catkin seems to be elongate-ovoid in shape when combining the two fragments (Fig. 1c, c1).

The staminate inflorescence shown in Fig. 1d and d1 (counterpart) shows a catkin in a postfloral stage (MNHM PB 2000/9 LS). The length is $16 \mathrm{~mm}$, the width $3 \mathrm{~mm}$, and the preserved length of the peduncle is $4 \mathrm{~mm}$ (width $1 \mathrm{~mm}$ ). The bracts appear isolated along the rhachis, and no distinct stamen is preserved (Fig. 2c); however, there are several isolated clusters of pollen preserved.

The in situ preserved pollen is similar in all of the specimens (Figs. 3b, 4), rounded triangular and triporate with pores at the edges. The exine is comparatively thick and thickening toward the pores which are oval to elongate oval, sometimes slit-like, and show a prominent strengthening (anulus) around.
The surface of the thick exine is somewhat irregular and densely ornamented by irregularly arranged micro-coni to micro-verrucae, sometimes with a pointed tip (myricaceous surface, see below).

\section{Comparisons and discussion}

\section{Inflorescences}

Determination of the fossil material based on details of the individual flowers is difficult due to inadequate preservation. However, arrangement of the flowers along the inflorescence, shape of the bracts, development of the inflorescence, and pollen morphology in combination with micro-ornamentation of the exine allow for an unequivocal determination to the family level.

The staminate inflorescences of our material may be characterised as typical catkins in the sense of Cronk et al. (2015): "a type of compact or string like inflorescence characterised by a single relatively stout axis on which unisexual sessile or subsessile apetalous flowers are clustered in a spiral or whorled arrangement". Staminate catkins today are especially found in some of the Fagales, Salicaceae, and some Piperaceae. However, Salicaceae and Piperaceae can be excluded from comparison to our material because of pollen morphological characters with Salicaceae being tricolpatereticulate (e.g. Beug 2004) or nearly inaperturate in Populus (Zavada and Dilcher 1986) and Piperaceae being monosulcate or inaperturate (e.g. Sampson 2000). The same is true within the Fagales for Fagaceae with their exclusively tricol(por)ate pollen (Grímsson et al. 2016) and the monotypic Nothofagaceae which are polycolporate (Fernández et al. 2016).
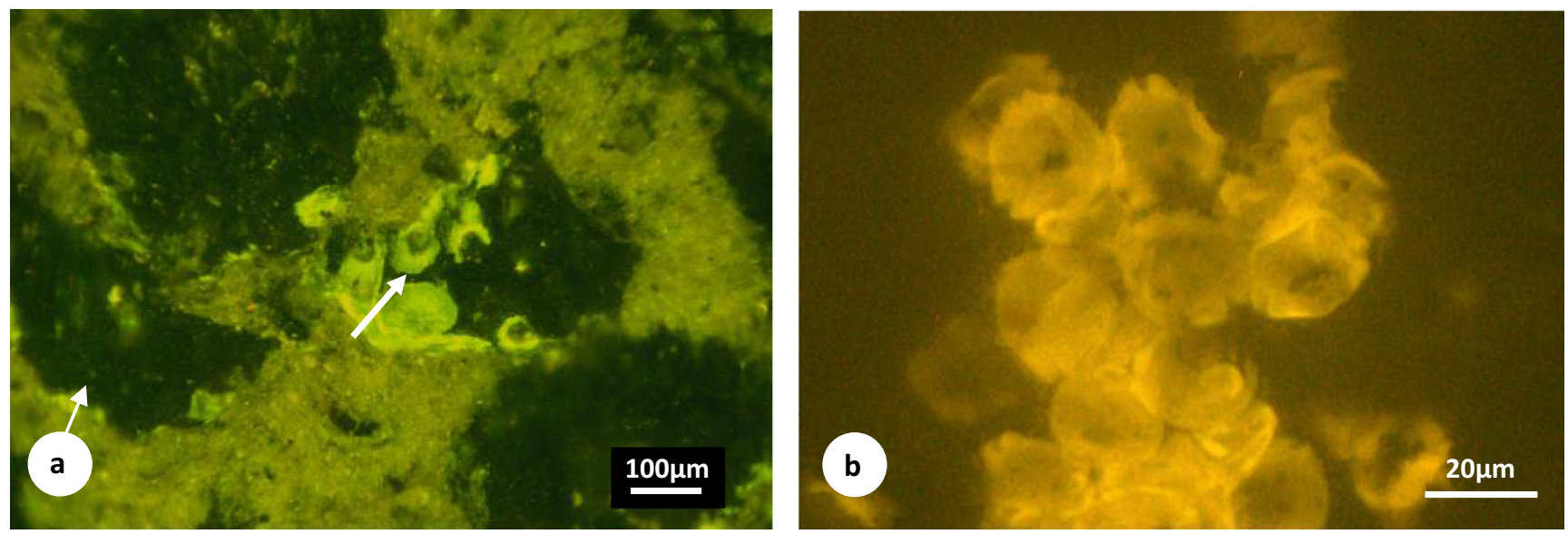

Fig. 3 Epifluorescence of peltate scales and pollen cluster of Myricamentum eckfeldensis $\mathrm{n}$. gen. et sp. from the middle Eocene of Eckfeld (Eifel Hills, Rhineland Palatinate, western Germany). a Peltate scales on the surface of MNHM PB 2020/577 LS. b Pollen cluster of MNHM PB 2020/577 LS in situ 

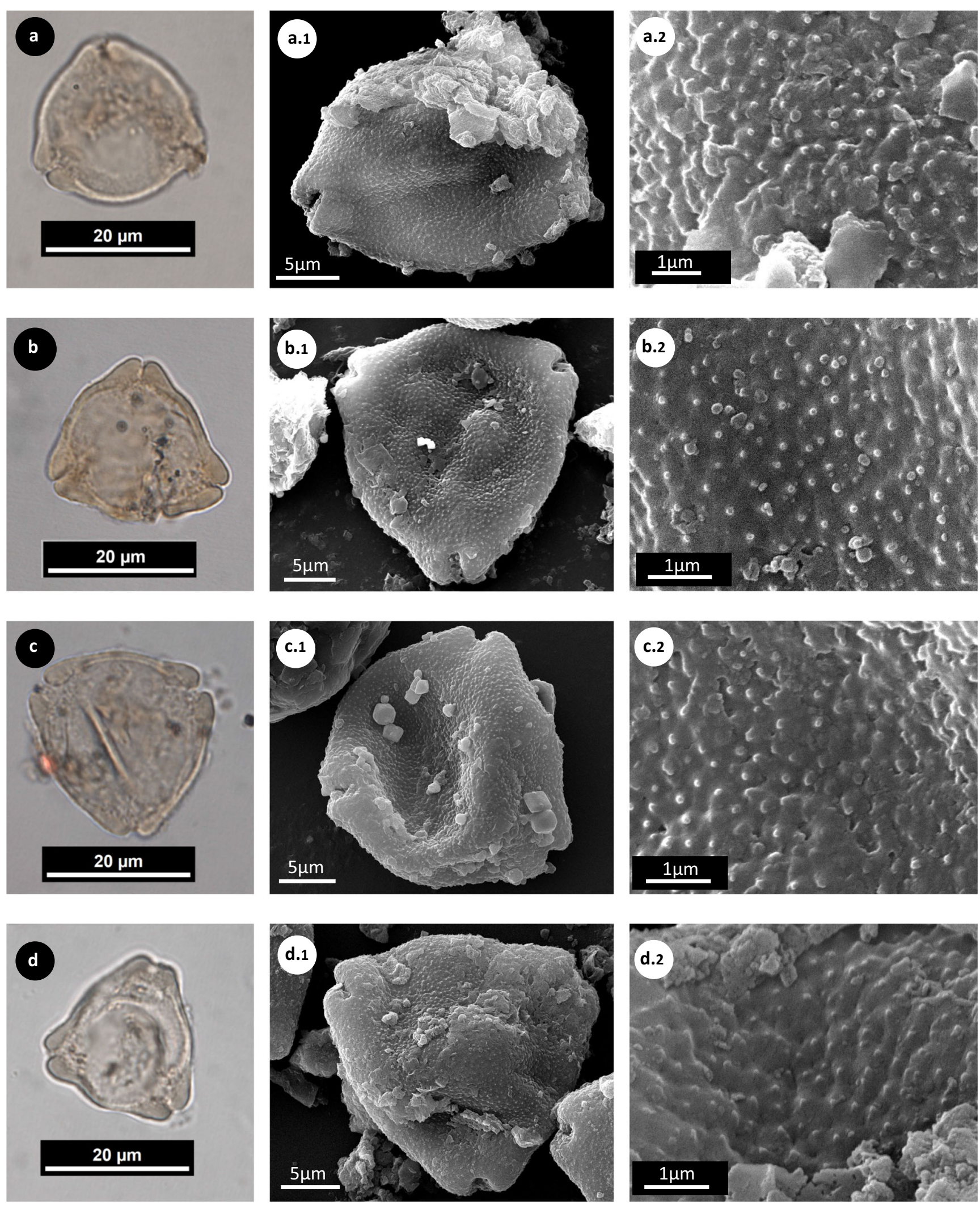

Fig. 4 In situ pollen grains from catkins of of Myricamentum eckfeldensis n. gen. et sp. (middle Eocene of Eckfeld, Eifel Hills, RhinelandPalatinate, western Germany). Left: LM overview. Middle: SEM

overview. Right: Detail of micro-ornamentation. a Specimen MNHM PB 2020/577 LS. b Specimen MNHM PB 2000/2 LS. c Holotype MNHM PB 2000/7 LS. d Specimen MNHM PB 2000/9 LS 
Triporate pollen superficially similar to that recovered from our fossils today is limited to Fagales sensu APG III (2009) and APG IV (2016), especially to a distinct clade (Li et al. 2004) comprising Betulaceae, Casuarinaceae, Juglandaceae, Myricaceae, Rhoipteleaceae (now included in Juglandaceae: APG III 2009), and Ticodendraceae. According to our comparisons which are based on SEM studies of taxa available to us and figured material of unavailable taxa, three basic types of microornamentation of the pollen surface may be recognised here (Fig. 5) and show a characteristic distribution within the respective clade (Fig. 6). (1) The juglandaceous surface (Fig. 5a) is clearly distinguished by a smooth surface of the grains which is more or less densely covered by individual micro-coni that may sometimes be arranged in a regular pattern. It is found in all genera and species of extant Juglandaceae and in the monotypic Rhoipteleaceae (e.g. Stone and Broome 1971, 1975). (2) The betulaceous surface (Fig. 5b) is characterised by micro-coni or micro-verrucae which are arranged on individual but irregularly distributed short ridges which are clearly separated by furrows. This type of pollen surface today is found in all Betulaceae (e.g. Chen 1991) and in Ticodendron, the single extant representative of the Ticodendraceae (Feuer 1991). Casuarinaceae also produce pollen of the betulaceous type (Coetzee and Praglowski 1984). (3) The myricaceous surface (Fig. 5c) is characterised by a slightly irregular surface of the individual grains which have a dense cover of irregularly arranged micro-coni to micro-verrucae. This type of pollen surface which has been found in our fossil material today is typical for Myricaceae (e.g. Coetzee and Praglowski 1984; Ferguson 1998; Punt et al. 2002).

The pollen recovered from our catkins unequivocally shows a myricaceous type of surface (Fig. 4). Aside from the pollen morphology, the male catkins may serve as another distinguishing character. In Betulaceae and Juglandaceae (except for Rhoiptelea which has no catkins but isolated hermaphroditic flowers on long axes), they extend during anthesis to reveal pollen by isolating the flowers and exposing the anthers. In the Casuarinaceae, separate whirls of individual male flowers are arranged along a common long axis (e.g. Dilcher et al. 1990). Comparing our specimen presumably in pre-anthesis (Fig. 1a + b) with the one in anthesis (Fig. 1c+ c1), no stretching of the catkin may be observed (Fig. $1 \mathrm{c}+\mathrm{c} 1$ versus Fig. $2 d+e)$. However, the bracts which were closely pressed against each other in the pre-anthesis specimen (Fig. $1 \mathrm{a}+\mathrm{b}$, Fig. $2 \mathrm{a}+\mathrm{b}$ ) are later separated by the spreading anthers and the release of pollen (Fig. $2 d+e$ ), thus giving rise to a much more voluminous appearance in the anthesis specimen. The bracts remained separate in the specimen which is presumably preserved in the postfloral state with the anthers and most of pollen having been shed (Fig. $1 d+d 1$, Fig. $2 c$ ). Together with the pollen surface, this kind of succession in the development of the catkins today is only known from the Myricaceae.

Pollen of Comptonia has a typical myricaceous surface; however, it regularly includes tetraporate grains (personal observations) which could exclude the genus from further comparisons to our material. Canacomyrica also has myricoid pollen (Sundberg 1985). According to recent concepts, Myrica and Morella are distinguished mainly by dry versus fleshy fruits (Herbert 2005a, b), and there is no obvious difference in pollen morphology (Sundberg 1985). Therefore our catkins can unequivocally be assigned to Myricaceae, possibly excluding Comptonia. Due to the extremely endemic distribution of Canacomyrica, they most probably represent the Myrica-Morella core alliance. In contrast to our material, the figured pollen grains of Myrica goeppertii KohlmanAdamska et al. 2004 from the late Miocene of Poland which were assigned to Triatriopollenites (resp. Myricipites) bituitus (Potonié 1931) Thomson and Pflug 1953 do not show a typical myricaceous micro-ornamentation but more isolated micro-verrucae or micro-coni. Further comparisons of the two species are difficult since shape of the bracts in $M$. goeppertii, and the number of anthers per bract in our material remains unclear.

\section{Comparison of in situ and dispersed pollen}

The pollen which was isolated from our fossils can clearly be assigned by LM to the dispersed species Triatriopollenites excelsus (Potonié 1931) Pflug in Thomson and Pflug 1953 as described in Thomson and Pflug (1953). Especially characteristic for the species, which is hardly distinguished from $T$. rurensis Pflug and Thomson in Thomson and Pflug 1953, is the
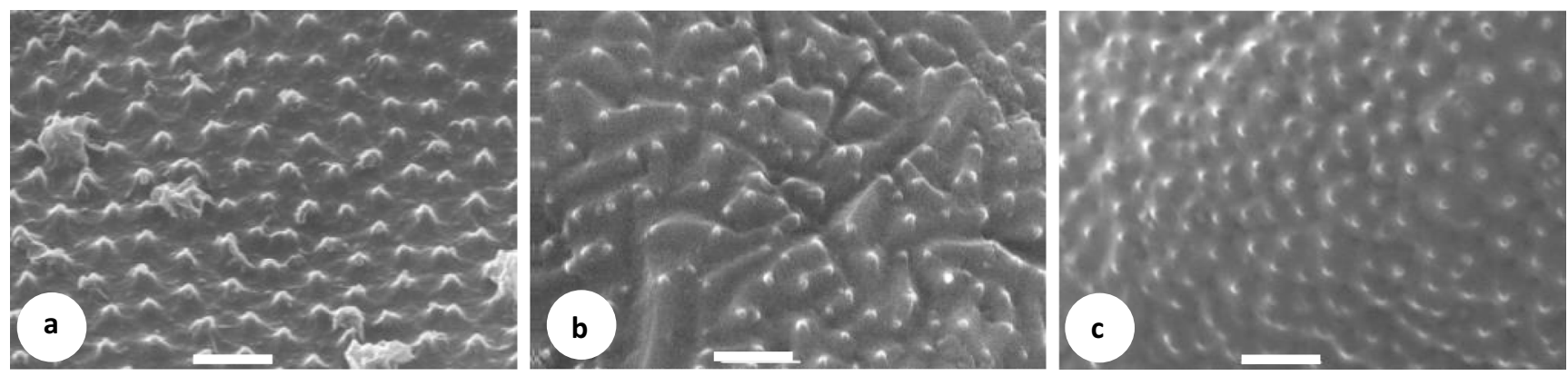

Fig. 5 Different types of micro-ornamentation of the surface of the exine in triporate Fagales pollen (Scales $1 \mu \mathrm{m})$ : a juglandoid (Carya cordiformis), b betuloid (Ostrya carpinifolia), and c myricoid (Myrica gale) 

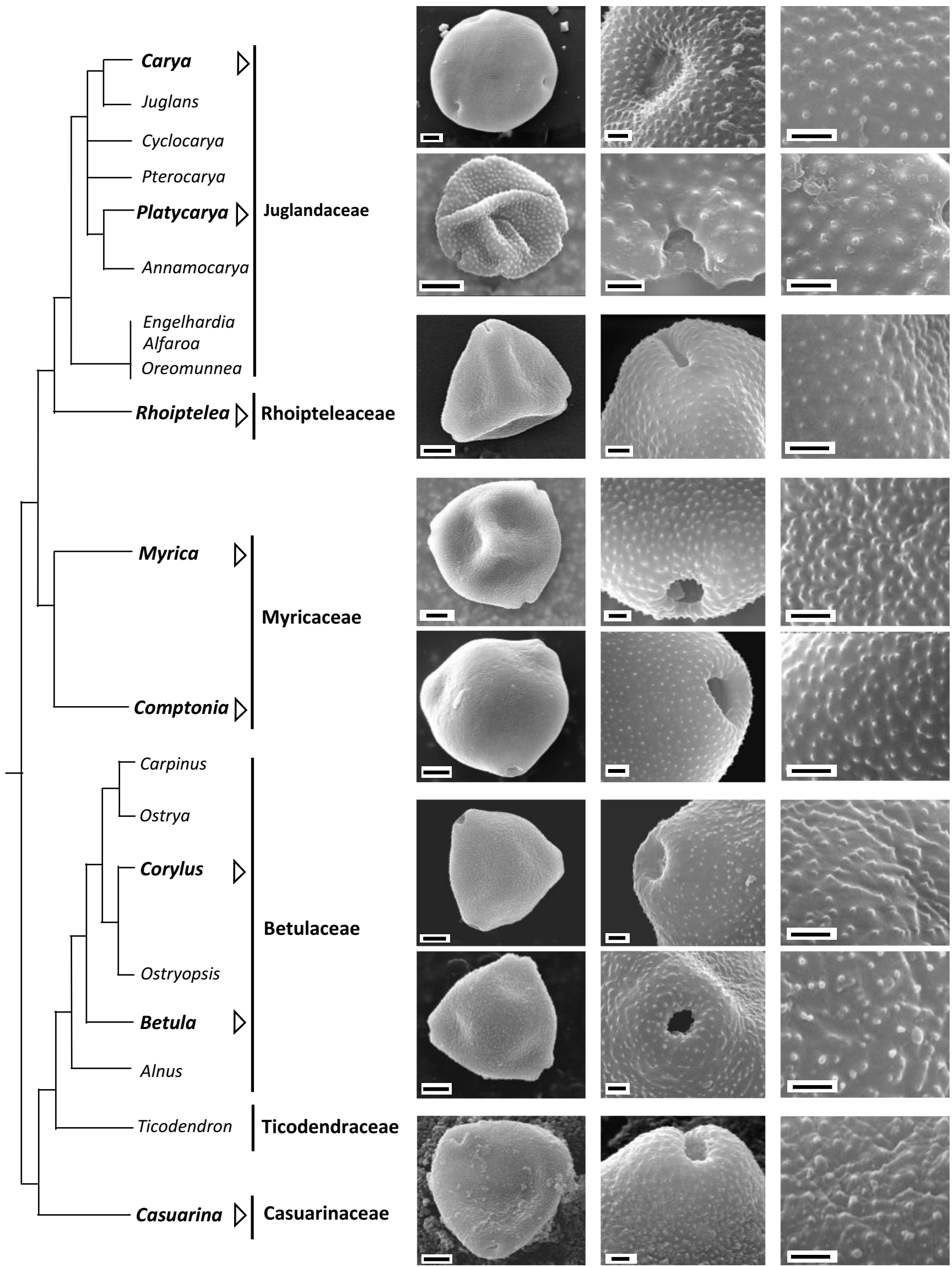
Fig. 6 Phylogenetic tree of Fagales with triporate pollen according to $\mathrm{Li}$ et al. (2004); to the right SEM images of individual grains (scale $5 \mu \mathrm{m}$ ), their pores (scale $1 \mu \mathrm{m}$ ) and micro-ornamentation (scale $1 \mu \mathrm{m}$ ) of selected genera (in bold and with arrows pointing to the respective images). Species figured from top to bottom are Carya cordiformis, Platycarya strobilacea, Rhoiptelea chiliantha, Myrica gale, Comptonia peregrina, Corylus avellana, Betula papyrifera, and Casuarina equisetifolia

combination of atrium and anulus which has even been described as "excelsus-type" by Thomson and Pflug (1953). According to size and minor differences in the development of the pores subspecies were distinguished in T. excelsus by Thomson and Pflug (1953), however, their reliability needs to be the subject of a major revision which is beyond the scope of the present paper. We cannot follow Krutzsch (1957) in distinguishing the Miocene type from the older (Eocene) material by a new species name ("pseudoexcelsus") which is not based on characters but only on age difference. Krutzsch (1961) later even transferred his new (older) species to Plicapollis while stating a close relationship to some members of the extinct Normapolles group. Accordingly, the dispersed material from Eckfeld has been determined as Plicapollis pseudoexcelsus (Krutzsch 1957) Krutzsch 1961 and was assigned to the Normapolles group by Nickel (1996). A vestibulum has originally been regarded as typical for Plicapollis Pflug 1953, but it cannot be seen in our material and is missing in the dispersed material from Eckfeld (Nickel 1996). However, in contrast some folding of individual grains often results in structures which were called plicae by Pflug (1953). This is a subordinate "ancient" character for Plicapollis that has frequently been observed in the dispersed (Nickel 1996) and in our in situ material from Eckfeld but was already mentioned in the description for Triatriopollenites excelsus by Thomson and Pflug (1953). This is slightly in contrast to the view of Thiele-Pfeiffer (1988) who separated plicate and nonplicate grains in the middle Eocene of Messel and assigned them to Plicapollis pseudoexcelsus (Krutzsch 1957) Krutzsch 1961 (Normapolles) and Triatriopollenites excelsus (Potonié 1931) Thomson and Pflug 1953 ("myricaceoid"), respectively. Due to a strong anulus, Thiele-Pfeiffer (1988) distinguished the latter species from younger "Myrica-type" grains.

Triatriopollenites excelsus was tentatively assigned to the Myricaceae already by Thomson and Pflug (1953). This is now strongly supported by the myricaceous microornamentation of the in situ grains from our fossils; however, Casuarinaceae cannot be excluded from pollen alone.

The widely defined Normapolles group consists of oblate triaperturate pollen with porate to slit-like and more or less prominent apertures (e.g. Pflug 1953; Góczán et al. 1967; Friis et al. 2006) which are extremely diverse in the Cretaceous (e.g. Góczán et al. 1967; Kedves and Diniz 1983: Polette and Batten 2017) and became extinct before the end of the Paleogene. A number of flowers/inflorescences with Normapolles-type pollen have been described from the middle and late Cretaceous (e.g. Friis 1983; Sims et al. 1999; Schönenberger et al. 2001; Friis et al. 2003, 2006; Heřmanová et al. 2011, 2017). However, there is only a single taxon with pollen superficially similar to the pollen from our material (Caryanthus Friis 1983). Those pollen were compared to pollen of extant Rhoiptelea (Sims et al. 1999; Friis et al. 2006).

\section{Conclusions}

The late middle Eocene male catkins as described in the present paper are the oldest record of male inflorescences unequivocally comparable to those of extant Myricaceae. The pollen included clearly shows a myricoid micro-ornamentation but may sometimes recall members of the extinct Normapolles group which were previously compared to pollen of extant Rhoipteleaceae, a monotypic family nested at the base of a clade formed together with the Juglandaceae ( $\mathrm{Li}$ et al. 2004) (and now even included in the Juglandaceae: APG III 2009) which is sister to the Myricaceae. Preservation of the loosely organised catkins most probably excludes transport to the site of deposition in the late middle Eocene maar lake at Eckfeld over some distance. Therefore, they have most probably been derived from ?low growing trees or shrubs on the slopes of the crater structure or along the edge of the lake.

Acknowledgements We thank the herbarium of the Muséum National d'Histoire Naturelle Paris for providing fascicles of Rhoiptelea for pollen sampling. Thanks are also due to Walter Riegel for discussions on fossil triporate pollen and to Stefan Dressler for hints regarding to nomenclature (both Senckenberg Forschungsinstitut und Naturmuseum Frankfurt am Main). Comments of S.R. Manchester and an anonymous reviewer helped to improve the manuscript finally.

Funding Open Access funding enabled and organized by Projekt DEAL.

\section{Compliance with ethical standards}

Conflict of interest The authors declare that they have no conflict of interest.

Open Access This article is licensed under a Creative Commons Attribution 4.0 International License, which permits use, sharing, adaptation, distribution and reproduction in any medium or format, as long as you give appropriate credit to the original author(s) and the source, provide a link to the Creative Commons licence, and indicate if changes were made. The images or other third party material in this article are included in the article's Creative Commons licence, unless indicated otherwise in a credit line to the material. If material is not included in the article's Creative Commons licence and your intended use is not permitted by statutory regulation or exceeds the permitted use, you will need to obtain permission directly from the copyright holder. To view a copy of this licence, visit http://creativecommons.org/licenses/by/4.0/. 


\section{References}

Abbe, E. C. (1974). Flowers and inflorescences of the "Amentiferae". Botanical Review, 40(2), 159-261.

APG III. (2009). An update of the angiosperm phylogeny group classification for the orders and families of flowering plants: APG III. Botanical Journal of the Linnean Society, 181, 1-20.

APG IV. (2016). An update of the angiosperm phylogeny group classification for the orders and families of flowering plants: APG VI. Botanical Journal of the Linnean Society, 161, 105-121.

Beug, H.-J. (2004). Leitfaden der Pollenbestimmung für Mitteleuropa und angrenzende Gebiete. München: Verlag Dr. Friedrich Pfeil.

Chen, Z.-D. (1991). Pollen morphology of the Betulaceae. Acta Phytotaxonomica Sinica, 26(6), 494-503.

Chourey, M. S. (1974). A study of the Myricaceae from Eocene sediments of southeastern North America. Palaeontographica B, 146(1-3), 88-153.

Coetzee, J. A., \& Praglowski, J. (1984). Pollen evidence for the occurrence of Casuarina and Myrica in the Tertiary of South Africa. Grana, 23(1), 23-41.

Collinson, M. E., Manchester, S. R., \& Wilde, V. (2012). Fossil fruits and seeds of the Middle Eocene Messel biota, Germany. Abhandlungen der Senckenberg Gesellschaft für Naturforschung, 570, 1-251.

Cronk, C. B., Needham, I., \& Rudall, P. J. (2015). Evolution of catkins: Inflorescence morphology of selected Salicaceae in an evolutionary and developmental context. Frontiers in Plant Science, 6(Article 1030), 1-13.

Dilcher, D. L., Christophel, D. C., Bhagwandin Jr., H. O., \& Scriven, L. J. (1990). Evolution of the Casuarinaceae: Morphological comparisons of some extant species. American Journal of Botany, 77(3), 338-355.

Engler, A. (1894). Myricaceae. In A. Engler \& K. A. Prantl (Eds.), Die natürlichen Pflanzenfamilien III,1 (pp. 26-29). Leipzig: Verlag Wilhelm Engelmann.

Ferguson, D. K. (1998). The contribution of micromorphology to the taxonomy and fossil record of the Myricaceae. Taxon, 47(2), 333335 .

Fernández, D. A., Santamarina, P. E., Tellería, M. C., Palazzesi, L., \& Barreda, V. D. (2016). Pollen morphology of Nothofagus (Nothofagaceae, Fagales) and its phylogenetic significance. Acta Palaeobotanica, 56(2), 223-245.

Feuer, S. (1991). Pollen morphology and systematic relationships of Ticodendron incognitum. Annals of the Missouri Botanical Garden, 78, 143-151.

Frankenhäuser, H., \& Wilde, V. (1993). Flowers from the Middle Eocene of Eckfeld (Eifel, Germany) - A first note. In J. F. W. Negendank \& B. Zolitschka (Eds.), Paleolimnology of European maar lakes. Lecture Notes in Earth Sciences 49, 491-497.

Franzen, J. L. (1993). Das biostratigraphische Alter der Fossillagerstätte Eckfelder Maar bei Manderscheid (Eifel). Mainzer naturwissenschaftliches Archiv, 31, 201-214.

Friis, E. M. (1983). Upper Cretaceous (Senonian) floral structures of Juglandalean affinity containing Normapolles pollen. Review of Palaeobotany and Palynology, 39(1/2), 161-188.

Friis, E. M., Pedersen, K. R., \& Schönenberger, J. (2003). Endressianthus, a new Normapolles-producing plant genus of Fagalean affinity from the Late Cretaceous of Portugal. International Journal of Plant Sciences, 164(5 Suppl), S201-S223.

Friis, E. M., Pedersen, K. R., \& Schönenberger, J. (2006). Normapolles plants: A prominent component of the Cretaceous rosid diversification. Plant Systematics and Evolution, 260, 107-140.

Góczán, F., Groot, J. J., Krutzsch, W., \& Pacltová, B. (1967). Die Gattzungen des "Stemma Normapolles Pflug 1953b" (Angiospermae). Neubeschreibungen und Revision europäischer Formen
(Oberkreide bis Eozän). Paläontologische Abhandlungen B, 2(3), 429-539.

Grímsson, F., Grimm, G. W., Zetter, R., \& Denk, T. (2016). Cretaceous and Paleogene Fagaceae from North America and Greenland: Evidence for a Late Cretaceous split between Fagus and the remaining Fagaceae. Acta Palaeobotanica, 56(2), 247-305.

Herbert, J. (2005a). Systematics and biogeography of the Myricaceae. A thesis submitted for the degree of PhD at the University of St. Andrews. St. Andrews: University of St. Andrews. Electronically available under: http://hdl.handle.net/10023/2687. Accessed 02/13/ 2020

Herbert, J. (2005b). New combinations and a new species in Morella (Myricaceae). Novon, 15, 293-295.

Heřmanová, Z., Kvaček, J., \& Friis, E. M. (2011). Budvaricarpus serialis Knobloch \& Mai, an unusual new member of the Normapolles complex from the Late Cretaceous of the Czech Republic. International Journal of Plant Sciences, 172(2), 285-293.

Heřmanová, Z., Dašková, J., Ekrt, B., \& Kvaček, J. (2017). Zlivifructus gen. nov., a new member of the Normapolles complex. Review of Palaeobotany and Palynology, 246, 177-184.

Heywood, V. H. (1993). Flowering plants of the world (Updated ed.). New York: Oxford University Press.

Kedves, M., \& Diniz, F. (1983). Les Normapolles du Crétacé supérieur en Europe: implications paléobiogéographiques. Geobios, 16(3), 329 345.

Kohlman-Adamska, A., Ziembińska-Tworzydło, M., \& Zastawniak, E. (2004). In situ pollen in some flowers and inflorescences in the Late Miocene flora of Sośnica (SW Poland). Review of Palaeobotany and Palynology, 132, 261-280.

Krutzsch, W. (1957). Sporen- und Pollengruppen aus der Oberkreide und dem Tertiär Mitteleuropas und ihre stratigraphische Verteilung. Zeitschrift für Angewandte Geologie, 1957(11/12), 509-548.

Krutzsch, W. (1961). Beitrag zur Sporenpaläontologie der präoberoligozänen kontinentalen und marinen Tertiärablagerungen Brandenburgs. Berichte der Geologischen Gesellschaft in der Deutschen Demokratischen Republik für das Gesamtgebiet der geologischen Wissenschaften, 5(4), 290-343.

Krutzsch, W. (1976). Die Mikroflora der Braunkohle des Geiseltales, Teil IV: Die stratigraphische Stellung des Geiseltalprofils im Eozän und die sporenstratigraphische Untergliederung des mittleren Eozäns. Abhandlungen des Zentralen Geologischen Instituts, 26, 48-92.

Lenz, O. K. (2005). Palynologie und Paläoökologie eines Küstenmoores aus dem Mittleren Eozän Mitteleuropas-Die Wulfersdorfer Flözgruppe aus dem Tagebau Helmstedt, Niedersachsen. Palaeontographica B, 271(1-6), 1-157.

Li, R.-Q., Chen, Z.-D., Lu, A.-M., Soltis, D. A., Soltis, P. S., \& Manos, P. S. (2004). Phylogenetic relationships in Fagales based on DNA sequences from three genomes. International Journal of Plant Sciences, 165(2), 311-324.

Macdonald, A. D. (1989). The morphology and relationships of Myricaceae. In P. R. Crane \& S. Blackmore (Eds.), Evolution, systematics, and fossil history of the Hamamelidae, Volume 2. "Higher" Hamamelidae. Systematics Association Special Volume, $40 B$ (pp. 147-165). Oxford: Clarendon Press.

Mai, D. H. (1995). Tertiäre Vegetationsgeschichte Europas. Jena: Gustav Fischer Verlag.

Muller, J. (1981). Fossil pollen records of extant angiosperms. Botanical Review, 47(1), 1-140.

Neuffer, F. O., Gruber, G., Lutz, H., \& Frankenhäuser, H. (1996). Das Eckfelder Maar, Zeuge tropischen Lebens in der Eifel. Mainz: Naturhistorisches Museum Mainz/Landessammlungen für Naturkunde Rheinland-Pfalz.

Nickel, B. (1996). Die mitteleozäne Mikroflora von Eckfeld bei Manderscheid/Eifel. Mainzer Naturwissenschaftliches Archiv Beiheft, 18, 1-147. 
Pflug, H. D. (1953). Zur Entstehung und Entwicklung des angiospermiden Pollens in der Erdgeschichte. Palaeontographica B, 95(4-6), 60-171.

Polette, F., \& Batten, D. J. (2017). Fundamental reassessment of the taxonomy of five Normapolles pollen genera. Review of Palaeobotany and Palynology, 243, 47-91.

Potonié, R. (1931). Zur Mikroskopie der Braunkohlen. Tertiäre Sporenund Blütenstaubformen (Vierte Mitteilung). Braunkohle, 30(27), 554-556.

Punt, W., Marks, A., \& Hoen, P. P. (2002). The Northwest European pollen flora, 66, Myricaceae. Review of Palaeobotany and Palynology, 123, 99-105.

Rüffle, L. (1976). Myricaceae, Leguminosae, Icacinaceae, Sterculiaceae, Nymphaeaceae, Monocotyledones, Coniferae. Abhandlungen des Zentralen Geologischen Instituts, 26, 337-438.

Sampson, F. B. (2000). Pollen diversity in some modern magnoliids. International Journal of Plant Sciences, 161(6 Suppl), S193-S210.

Schönenberger, J., Pedersen, K. R., \& Friis, E. M. (2001). Normapolles flowers of fagalean affinity from the Late Cretaceous of Portugal. Plant Systematics and Evolution, 226, 205-230.

Sims, H. J., Herendeen, P. S., Lupia, R., Christopher, R. A., \& Crane, P. R. (1999). Fossil flowers with Normapolles pollen from the Upper Cretaceous of southeastern North America. Review of Palaeobotany and Palynology, 106, 131-151.

Stone, D. E., \& Broome, C. R. (1971). Pollen ultrastructure: Evidence for relationship of the Juglandaceae and the Rhoipteleaceae. Pollen et Spores, 13(1), 5-14.

Stone, D. E., \& Broome, C. R. (1975). Juglandaceae A. Rich. Ex Kunth. World Pollen and Spore Flora, 4, 1-35.

Sundberg, M. D. (1985). Pollen of the Myricaceae. Pollen et Spores, 27(1), 15-28

Thiele-Pfeiffer, H. (1988). Die Mikroflora aus dem mitteleozänen Ölschiefer von Messel bei Darmstadt. Palaeontographica B, 211(1-3), 1-86.
Thomson, P. W., \& Pflug, H. (1953). Pollen und Sporen des mitteleuropäischen Tertiärs. Gesamtübersicht über die stratigraphisch und paläontologisch wichtigen Formen. Palaeontographica $B$, 94(1-4), 1-138.

Wilbur, R. L. (1994). The Myricaceae of the United States and Canada: Genera, subgenera, and series. Sida, 16(1), 93-107.

Wilde, V. (1989a). Untersuchungen zur Systematik der Blattreste aus dem Mitteleozän der Grube Messel bei Darmstadt (Hessen, Bundesrepublik Deutschland). Courier Forschungsinstitut Senckenberg, 115, 1-213.

Wilde, V. (1989b). Vorläufige Mitteilungen zur Flora aus dem Alttertiär von Eckfeld - Ergebnisse einer ersten Durchsicht des Fundmateriales aus den Grabungen von 1987 und 1988. Mainzer naurwissenschaftliches Archiv, 27, 23-31.

Wilde, V. (1995). Die Makroflora aus dem Mitteleozän des Geiseltalgebietes, kurze Übersicht und Vergleiche. Hallesches Jahrbuch für Geowissenschaften, Reihe B: Geologie, Paläontologie, Mineralogie, 17, 121-138.

Wilde, V. (2004). Aktuelle Übersicht zur Flora aus dem mitteleozänen "Ölschiefer" der Grube Messel bei Darmstadt (Hessen, Deutschland). Courier Forschungsinstitut Senckenberg, 252, 109114.

Wilde, V., \& Frankenhäuser, H. (1998). The Middle Eocene plant taphocoenosis from Eckfeld (Eifel, Germany). Review of Palaeobotany and Palynology, 101(1-4), 7-28.

Wilde, V., \& Frankenhäuser, H. (1999). Comptonia-like leaves from the German Middle Eocene. Acta Palaeobotanica Supplementum, 2, 447-463.

Zavada, M. S., \& Dilcher, D. L. (1986). Comparative pollen morphology and its relationship to phylogeny of pollen in the Hamamelidae. Annals of the Missouri Botanical Garden, 73(2), 348-381.

Publisher's note Springer Nature remains neutral with regard to jurisdictional claims in published maps and institutional affiliations. 